\title{
Aspects of reproductive performance in small ruminants - opportunities and challenges
}

\author{
J. P. Hanrahan \\ Teagasc, Sheep Research Centre, Athenry, Co. Galway, Ireland
}

\begin{abstract}
Ovulation rate is the principal source of variation in the reproductive rate of small ruminants. There is extensive variability in this trait both in terms of major genes and polygenes. Identification of the DNA changes responsible for the Booroola and Inverdale effects enabled testing for these mutations in any population. Surprisingly, in only one of six populations, with segregation of major genes for ovulation rate, could the effect be attributed to one of these mutations. Current evidence shows that there are five distinct loci that have large effects on ovulation rate. Selection on ovulation rate in Finn sheep produced a 2.2-fold change without any evidence for major gene involvement. The response appears to reflect changes in the thresholds that control the number of ova shed, indicating that a fundamentally different mechanism is involved from those shown for Booroola and Inverdale genes, and probably other major genes. The results also indicate that the variability of ovulation rate, for a given mean value, can be reduced by genetic selection. This has direct implications for neonatal survival, which declines rapidly as the size of the litter at birth increases above two - a major limitation on the exploitation of the known major genes. The effectiveness of genetic improvement programmes, especially in sheep, would be greatly enhanced if the problem of poor pregnancy rate from cervical insemination of frozen-thawed semen was solved. Recent studies reveal major differences among ewe breeds and large ram-to-ram variation in pregnancy rate from cervical AI with frozenthawed semen. Identification of the basis for ram-to-ram variation could be exploited immediately in selecting rams for Al. Progress in this area would greatly facilitate the exploitation of molecular genetic information in the genetic improvement of small ruminants.
\end{abstract}

\section{Introduction}

The predominant theme in the study of reproduction of sheep and goats has been female fecundity. This area of study was clearly justified by the obvious fundamental importance of female reproduction but also by the impact of female reproductive rate on the biological efficiency of meat production (Dickerson, 1970; Large, 1970). This general concern was 
addressed through a focus on litter size and seasonality as the key constraints in the biological efficiency of small ruminant systems. The prevailing paradigm in the 1950s and 1960s in relation to prolificacy was that genetic variation was very limited and, with very low heritability, within-breed selection was not likely to be a productive endeavour (Reeve and Robertson, 1953).

The general view that genetic variation within breeds was insufficient for effective genetic improvement of reproductive rate was challenged by the early results from selection experiments on litter size in Romney (Wallace, 1958) and Merino (Turner et al, 1962) sheep. In the Northern Hemisphere, the genetic option was realized through the 'discovery' of the exceptionally high reproductive rate of Finn sheep, which were imported to the UK in 1962 and to Ireland in 1965, and the Romanov and Finn sheep which were imported into France at about the same time. Other initiatives during this period were, in retrospect, of central importance to current developments in the understanding of female reproduction - these were the 'import' of Booroola Merinos into the research flocks of sheep in CSIRO in Australia (Turner, 1982) and the application of very intense selection (screening) of sheep populations for individual ewes with exceptional prolificacy in the UK (Owen, 1971) and Ireland (Timon et al., 1963).

The 'discovery' of prolific Finn and Romanov breeds led to a cascade of studies based on the difference in prolificacy between breeds and related studies (Fahmy, 1996). One of the early conclusions from this work was that a high ovulation rate was the central characteristic of prolific sheep and their crosses, and that ovulation rate was the key variable underlying genetic variation in litter size (Hanrahan, 1980). The study of ovulation rate has been a central concern in the research on reproductive performance during the last 25 years. After the initial focus on the Finn and Romanov breeds as the source of diversity in the design of studies on the control of ovulation rate, the focus moved firmly to studies of single gene effects. This followed the demonstration that the exceptional prolificacy of Booroola Merinos was attributable to a single locus with two alleles - one of which had an additive effect, of the order of 1.5 ova, on ovulation rate (Davis et al., 1982; Piper and Bîndon, 1982).

There has been much less emphasis on male reproduction and certainly nothing to parallel the worldwide effort on the genetic and physiological aspects of ovulation rate and its control. There is an urgent need for renewed effort in studies of cryopreservation of semen of small ruminants and on associated Al without reliance on the use of laparoscopic procedures for intra-uterine deposition of semen. This would greatly enhance genetic improvement programmes and facilitate the exploitation of the biotechnology revolution.

In this paper, information on genetic variation in ovulation rate will be summarized and discussed in relation to embryo mortality, and the prospects for limiting the incidence of triplet and higher order litters, and thus enhancing offspring survival, by changing the distribution of ovulation rate will be discussed. Recent studies on cervical Al using frozen-thawed semen will be presented to highlight topics that require research and that may present opportunities for progress towards enabling the more widespread exploitation of $\mathrm{Al}$ in sheep and goat breeding.

\section{Genetic variation in ovulation rate}

\section{Polygenic variation}

There is an abundance of evidence on the differences among sheep breeds in ovulation rate with mean values ranging from about 1.5 to 4.0 , excluding the involvement of major genes. The evidence for variation among goat breeds indicates a similar range but there are few comparative studies. The heritability of ovulation rate is expected to be greater than that 
Table 1. Response to divergent selection on ovulation in Finn sheep - ewes born from 1993 to 1997

\begin{tabular}{lrr}
\hline & \multicolumn{2}{c}{ Mean $( \pm$ SE) ovulation rate at } \\
\cline { 2 - 3 } Selection line & $8-10$ months & 18 months \\
\hline Low & $1.6 \pm 0.051$ & $2.1 \pm 0.058$ \\
Control & $2.0 \pm 0.049$ & $2.6 \pm 0.054$ \\
High & $3.7 \pm 0.041$ & $4.6 \pm 0.045$ \\
\hline
\end{tabular}

"Low: selected for low ovulation rate; control; unselected contról line; high: selected for high ovulation rate.

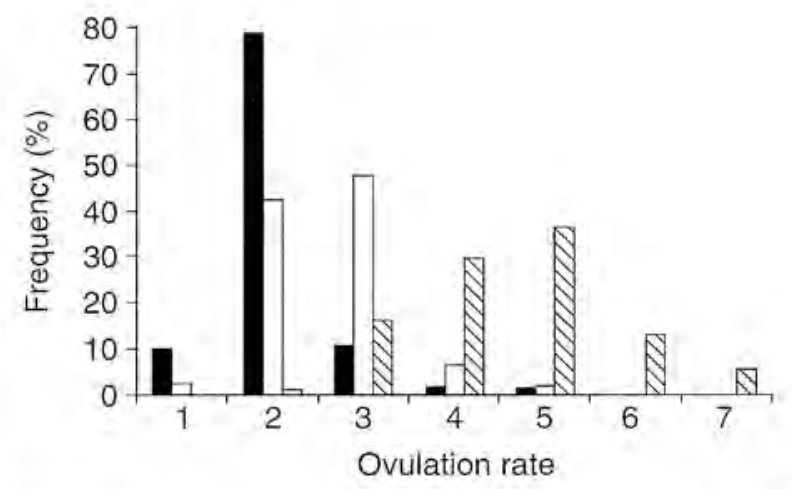

Fig. 1. Distribution of ovulation rate in 18-month-old Finn ewes from lines produced by divergent selection on ovulation rate (low; $\mathbb{Q}$ : high) and in an unselected control ( $\square)$ line.

for litter size as a result of the influence of embryo wastage (Hanrahan, 1982). A review of published estimates yielded an average value of 0.21 but estimates for the prolific Finn $(0.50)$ and Romanov (0.39) breeds were considerably higher (Fogarty, 1995). Divergent selection for ovulation rate in the Finn breed has confirmed the availability of a considerable amount of genetic variation (Hanrahan, 2002). Over the last 5 years of this experiment, the High line (selected for high ovulation rate) had a mean ovulation rate that was 2,2 times that of the Low line (selected for low ovulation rate) (Table 1). The distribution of ovulation rate in these lines (Fig. 1) shows a transition to a symmetrical 'normal' pattern in response to selection. Analysis of the variation within the lines did not yield any evidence that a gene with large effect was involved (Hanrahan, 2002). It is likely that a similar degree of genetic variation is available for exploitation in any population of sheep or goats but the rate of selection response will depend on the actual mean value.

\section{Single gene effects}

The discovery that the high prolificacy of Booroola Merino sheep was due to a gene with a large effect on litter size (Davis et al., 1982; Piper and Bindon, 1982) provided a new perspective on the genetics of fecundity in sheep and this new paradigm quickly led to evidence for major genes for prolificacy in other sheep populations. Thus, strong evidence was produced for segregation of a gene with a large effect on ovulation rate in the Cambridge (Hanrahan and Owen, 1985), Icelandic (Jonmundsson and Adalsteinsson, 1985) and Javanese (Bradford et al., 1986) breeds, initially. The list of breeds with putative major genes for 
fecundity was extended to include the Olkuska (Radomska et al., 1988), Creole (Mahieu, 1989), Belclare (Hanrahan, 1991) and the Romney (Davis et al., 1991a) breeds. The major gene in the Romney breed (called Inverdale) was subsequently shown to be X-linked (Davis et al., 1991b) and homozygous carriers were found to be sterile (Davis et al., 1992). Bodin et al. $(1998,2002)$ presented evidence for a major gene for prolificacy in the Lacaune breed and this gene has recently been shown to be on chromosome 11 (Mulsant et al., 2002). Davis et al. (2001) reported evidence that an X-linked imprinted gene with a large effect on ovulation rate is segregating in the Coopworth breed.

Despite considerable effort on physiological studies designed to identify the mechanisms responsible for the Booroola gene effect, the answer did not emerge until the application of molecular genetic techniques eventually identified the gene involved (Mulsant et al., 2001; Wilson et al., 2001). This discovery was preceded by the identification of the gene responsible for the X-linked Inverdale effect in Romney sheep (Galloway et al., 2000). The high prolificacy of Booroola Merino sheep is the result of a mutation in the bone morphogenetic protein $1 \mathrm{~B}$ receptor (ALK-6) that is expressed in both oocytes and granulosa cells (Wilson et al., 2001), whereas the high prolificacy in the Inverdales is due to a mutation in the gene for an oocytederived growth factor, known as bone morphogenetic protein 15 (Galloway et al., 2000). Montgomery et al. (2001) reviewed information on the mechanisms involved in major gene effects and concluded that genes influencing ovulation rate in sheep act primarily in the ovary.

The identification of the genes responsible for the Booroola and Inverdale effects provided the means for directly examining DNA from sheep in any population with a putative major gene to determine whether the Booroola $\left(F e c B^{B}\right)$ or Inverdale $\left(F e c X^{\prime}\right)$ mutations were implicated. The results of such an investigation (Davis et al., 2002) have been published and included data from Javanese, Icelandic, Olkulska, Lacaune, Belclare, Cambridge and Coopworth ewes selected as likely carriers of a putative major gene(s). Only the Javanese breed was found to have the $F e c B^{B}$ mutation, whereas $F e c X^{\prime}$ mutation was not present in any of the animals tested. This study also included the Garole breed which was known to have a large litter size and a likely connection with the Booroola Merino in Australia (Turner, 1982). The Garole sheep were found to be mostly homozygous for the Booroola gene and are therefore the likely origin of this mutation. The finding that only the Javanese sheep had one of the two mutations tested shows that there are other mutations with large effects on ovarian function that are yet to be identified in sheep. The identification of the genes responsible will add greatly to the understanding of the complex series of events that determine ovulation rate in sheep.

Studies of ovulation rate in the Cambridge and Belclare breeds have revealed the presence of sterile ewes with ovarian hypoplasia similar to that caused by the X-linked Inverdale gene (Hanrahan, 1991, 1997). Histological examination of ovaries from sterile ewes of both breeds has shown that follicle development was severely disrupted with all ovaries containing normal non-growing primordial follicles plus follicles with a large oocyte surrounded by a few cuboidal cells (J. C. Mariana, J. P. Hanrahan, A. Collett and A. Donovan, unpublished). In addition some ovaries had histological features, such as small follicles with an antrum and abnormal oocytes surrounded by abnormally dispersed layers of cells and oocytes with thickened zonae pellucidae, that were distinct from those described for sterile Inverdale ewes by Braw-Tal et al. (1993). It was concluded that the mutations responsible are different from the Inverdale mutations and, based on similarities with histological patterns in growth differentiation factor 9 (GDF9)-deficient mice (Dong et al., 1996), the GDF9 locus was identified as a likely candidate. This finding is consistent with results of Hanrahan (2001) designed to confirm earlier conclusions from proband analysis that an autosomal gene is responsible for ovarian hypoplasia in Cambridge and 
Belclare breeds (Hanrahan, 1997). The mating plan involved crossing ewes of the Galway breed (a low prolificacy breed in which no evidence for ovarian hypoplasia was seen in hundreds of cases examined for ovulation rate) with three Cambridge rams known to carry a gene for ovarian hypoplasia. Sons from these matings were back-crossed to Cambridge ewes known to carry a gene for ovarian hypoplasia. A total of 21 backcross ewe lambs were examined for ovarian status and four of these ewes had the typical ovarian hypoplasia phenotype. Thus, the hypothesis of X linkage was rejected. In the progeny from a Belclare carrier ram and Cambridge carrier ewes, one of five ewe lambs had the typical sterile phenotype. Thus, the same mutation is also present in the Belclare breed. Recent results from DNA sequencing of candidate loci indicate that both $\mathrm{X}$-linked and autosomal loci are involved in the Cambridge and Belclare breeds. Thus, we have shown that the sterile phenotype is associated in both breeds with homozygosity for single nucleotide substitutions in either BMP15 or GDF9 (J. P. Hanrahan, S. M. Gregan, P. Mulsant, M. Mullen, G. H. Davis, R. Powell and S. M. Galloway, unpublished).

\section{Embryo mortality}

The interaction between ovulation rate and embryo mortality determines litter size, given that the incidence of partial fertilization is very low in multiple ovulating females. At least $80 \%$ of ewes or does establish a pregnancy after exposure to fertile males for one oestrus under natural conditions (Gordon, 1997). It is well established for both sheep and goats that most embryo wastage occurs within the duration of an oestrous cycle and that there is a negative linear relationship between the number of eggs shed and rate of embryo loss. This is not a genetic relationship, as the same pattern occurs after natural mating and when embryo transfer is used to establish pregnancy.

The uterine environment provided by the dam and individual embryo constitution can be sources of genetic variation in embryo mortality. The heritability of embryo mortality as a trait of the dam is very low (Elsen et al., 1994). Embryo transfer experiments involving recipients from different breeds or lines have generally failed to reveal differences in maternal contributions to embryo survival (Hanrahan, 1982). However, other studies have provided evidence for such effects with a notably high embryo survival in the Romanov breed (Ricordeau et al, 1982). The evidence summarized by Hanrahan (1986) indicates that the probability of embryo survival in Romanov ewes is about 0.08 greater than in other breeds over the ovulation rate classes 1-3. There is also evidence for similarly high embryo survival in Icelandic ewes (Hanrahan et al., 1989). Studies by Bodin et al. (1994) provided evidence that the genotype of the embryo can be important in the determination of variation in survival within breeds in contrast to evidence on the absence of such effects in embryo transfer studies among breeds (Hanrahan, 1982). Nutritional factors can affect the embryo and the maternal milieu and this is an area of considerable current research interest which has been reviewed by $\mathrm{O}^{\prime}$ Callaghan and Boland (1999) and is likely to lead to important insights into the scope for genetic effects on embryo survival. It seems reasonable to conclude that both the dam and the embryo are sources of genetic variation in embryo mortality but, based on available evidence, the extent and relative importance of any such variation are generally limited under the normal range of production conditions.

\section{Offspring survival}

Most lamb mortality occurs either at about the time of parturition or within the first week of life. The same is probably true for kids and this peri-natal mortality is a major source of reproductive 
inefficiency. The number of offspring per litter has a major impact on the probability of survival and in well-managed sheep systems, typical survival rates would be about 92,86 and $75 \%$ for singletons, twins and triplets, respectively. The survival rate for quadruplets and higherorder birth types is likely to be $\ll 60 \%$. The rapid increase in mortality when litter size exceeds two has both economic and welfare implications and inhibits the exploitation of genetic opportunities for increased prolificacy. The interaction between prolificacy, survival and production system in relation to the economic value of increased litter size has been discussed by Bradford (1985) and Amer et al. (1999). The economic benefit from increased litter size, although generally large, varies considerably with the production system and declines as average prolificacy increases. Improvement of offspring survival would reduce the increase in prolificacy required to achieve a given target level of ewe productivity and facilitate exploitation of available genetic resources.

Genetic variation in offspring survival can be due to differences among dams in the environment that they provide for their progeny or due to genes expressed directly in the offspring. In the case of sheep the relative contribution of these sources shows that maternally expressed genes are more important than those expressed directly in the progeny. Average heritabilities of these two sources are 0.07 and 0.03, respectively (Fogarty, 1995). Results indicate that heritability may be higher in prolific populations, such as the Finnish Landrace (Matos et al., 2000). Selection for improved lamb survival has been effective (Cloete and Scholtz, 1998) and there is also evidence for considerable breed differences (Demiroren et al., 1995). Thus, genetic improvement in survival rate is attainable but the rate of genetic gain is likely to be low and it seems likely that the pattern of increased loss as litter size increases will persist.

Against this background, and the potential for exploiting single genes to increase litter size rapidly, there are both economic and welfare arguments for renewed research to identify the factors responsible for the large increase in peri-natal mortality associated with triplet and quadruplet births and to examine the prospects for reducing the incidence of triplet and higher order births while maintaining a high average level of prolificacy. Recent studies (for a review, see Robinson et al., 1999) showing the impact of nutrient supply and quality on the early embryo and on the growth and development of the fetus are likely to lead to a better understanding of how management practices can be used to maximize the probability of offspring survival from multiple births. The availability of single genes with large effects on ovulation rate provides a useful tool for studies on these issues as well as being an important reason for such studies.

\section{Reducing the variability of litter size}

An increase in the incidence of triplet and higher order multiple births is an undesirable side effect of increased average litter size (Bradford, 1985). A change in the nature of this relationship requires a reduction in the underlying variation in ovulation rate. To achieve a given mean ovulation rate but with different variability requires a change in how the underlying variation is expressed as discrete ova. If the number of ova shed represents an underlying normally distributed variable, the thresholds between each discrete ovulation rate can be expressed relative to units of the standard deviation $(\sigma)$ of the underlying variable and the distance between successive thresholds determines the variability in ovulation rate. These distances can be used to explore evidence for genetic effects on variability.

Results of studies on ovulation rate in Romanov and Finn sheep were summarized by Hanrahan (1986). The data yield an estimate of $1.7 \sigma$ for distance between the $2 / 3$ and $3 / 4$ thresholds in the Romanov breed, whereas the corresponding interval in the Finn breed is substantially less $(1.1 \sigma)$. The length of the $3 / 4$ to $4 / 5$ interval is $1.0 \sigma$ for Romanov and $0.9 \sigma$ 
Table 2. Effect of divergent selection for ovulation rate on the length (in $\sigma$ units) of the underlying threshold intervals

\begin{tabular}{|c|c|c|c|}
\hline \multirow[b]{2}{*}{ Threshold interval } & \multicolumn{3}{|c|}{ Selection line } \\
\hline & Low & Control & High \\
\hline $1 / 2: 2 / 3$ & $2.05^{\mathrm{ax}}$ & $2.02^{\mathrm{ax}}$ & 1.1.17bx \\
\hline $2 / 3: 3 / 4$ & $1.14^{\text {ay }}$ & $1.28^{\text {ay }}$ & $1.07^{\mathrm{ax}}$ \\
\hline $3 / 4: 4 / 5$ & - & $0.80^{\mathrm{ay}}$ & $0.87^{\mathrm{ax}}$ \\
\hline $4 / 5: 5 / 6$ & - & - & $0.81^{x}$ \\
\hline Total records & 913 & 933 & 1113 \\
\hline
\end{tabular}

Low: selected for low ovulation rate; control: unselected control line; high: selected for high ovulation rate.

alb Values in the same row without a common superscript are significantly different $(P<0.05)$.

xy Values in the same column without a common superscript are significantly different $(P<0.05)$.

for Finn. These data indicate a breed difference in the length of the $2 / 3: 3 / 4$ interval. Icelandic sheep show very little variation in ovulation rate and twin ovulation occurs in $80 \%$ of adult ewes (Hanrahan et al., 1989). The length of the $1 / 2: 2 / 3$ threshold interval for this breed was $3.3 \sigma$ which is substantially longer than that for the Romanov or Finn breeds (about $2.0 \sigma$ in both cases).

The selection lines of Finn sheep referred to earlier were also examined for evidence on the length of the various threshold intervals. A set of 26 separate estimates was generated by subdividing the observations by ewe age (ewe lamb versus 2-tooth ewe), year of birth (1980-1988 and 1990-1997) and selection line. There were about 250 observations for each sub-group. Analysis of the resulting threshold intervals (summarized in Table 2) shows a large and significant difference in the length of the $1 / 2: 2 / 3$ interval compared with subsequent intervals except for the High selection line. Thus, selection for high ovulation rate appears to have reduced the $2 / 3$ threshold without any significant effect on the intervals between successive higher threshold positions. There was no evidence for any effect of ewe age on the inter-threshold distance. This effect of selection is consistent with the comparison of Finn and Romanov breeds in which the only evident difference was in the length of the interval between the $2 / 3$ and $3 / 4$ thresholds. Although there may be difficulties in relation to the assumption that the variance of the underlying variable is constant, the evidence indicates that these two breeds differ in how ovulation rate is controlled. It is suggested that the mechanisms responsible for the high ovulation rate in the Finn and Romanov breeds are fundamentally different from those responsible for major gene effects, as alterations in the threshold intervals would not be expected to have the effects on repeatability of ovulation rate that are typical of the major gene effects described to date.

\section{Artificial insemination}

The fundamental importance and potential of this technology to enhance genetic improvement programmes for small ruminants is exemplified by international genetic evaluation procedures for dairy cattle. An essential ingredient in the efficacy of $\mathrm{Al}$ in cows is the fact that the insemination pipette can be passed through the cervix so that frozen-thawed semen can be deposited at appropriate locations in the uterus. The structure of the cervix in the ewe does not allow transcervical Al, whereas in a proportion (about one third) of does it is possible to effect intra-uterine Al via the cervix (Evans and Maxwell, 1987). Cervical Al of frozen-thawed semen generally yields an unacceptably low (10-30\%) pregnancy rate in sheep; the success rate in does is generally much better but depends on the depth of insemination achieved 
Table 3. Effect of ewe breed on pregnancy rate from cervical AI with frozen-thawed semen

\begin{tabular}{|c|c|c|c|c|}
\hline \multirow[b]{2}{*}{ Ewe breed } & \multicolumn{2}{|c|}{ Experiment $]^{\mathrm{a}}$} & \multicolumn{2}{|c|}{ Experiment $2^{b}$} \\
\hline & $\begin{array}{c}\text { Number of } \\
\text { ewes }\end{array}$ & $\begin{array}{c}\text { Pregnancy } \\
\text { rate }(\%)\end{array}$ & $\begin{array}{c}\text { Number of } \\
\text { ewes }\end{array}$ & $\begin{array}{c}\text { Pregnancy } \\
\text { rate }(\%)\end{array}$ \\
\hline Finnish Landrace & 60 & 57 & 35 & 77 \\
\hline Suffolk & - & - & 36 & 8 \\
\hline Texel & - & - & 54 & 28. \\
\hline Belclare & - & - & 25 & 44 \\
\hline Belclare $\times$ Scoltish Blackface & 104 & 54 & 40 & 43 \\
\hline Suffolk-cross & 133 & 38 & 56 & 19 \\
\hline
\end{tabular}

Donovan et al. (1998).

bonovan et al. (1999).

(Leboeuf et al, 2000; Salamon and Maxwell, 2000). Although intra-uterine insemination, using laparoscopic procedures, gives very good pregnancy rates $(60-70 \%)$ the use of this technique is likely to be limited because of the costs involved, restrictions on the conditions under which the surgical procedures required may be carried out, as well as welfare concerns.

An exception to the general finding of unacceptably low pregnancy rates in ewes after cervical Al of frozen-thawed semen is the evidence from Norway where non-return rates of $55-60 \%$ have been reported for field scale application over a number of years (Olesen, 1993). These results encouraged us to initiate a series of studies in Ireland using Norwegian protocols. The principal findings to date from these studies are presented in the following sections. In all of the experiments, semen was processed and frozen as described by Andersen-Berg and Aamdal (1991) and Olesen (1993). The processed semen was loaded into $0.25 \mathrm{ml}$ Minitub straws and frozen in liquid nitrogen vapour in a programmable freezer before it was plunged into liquid nitrogen for storage.

One of the first studies undertaken was to compare the semen from Norwegian breeds (collected and frozen in Norway) with semen collected and frozen in Ireland (mainly from Suffolk and Texel rams). This study failed to reveal any evidence for a difference in pregnancy rate between the Norwegian and Irish semen and it was concluded that the consistently good pregnancy rates achieved in Norway could not be attributed to a better inherent fertilizing ability of frozen-thawed semen from Norwegian breeds (Donovan et al., 1999, 2001). A range of ewe breeds was used in these studies and it was evident that this was an important determinant of pregnancy rate.

\section{Evidence for ewe breed effects}

The ewes used in the comparison of frozen semen from Norway and Ireland were all parous ewes that were either crossbreds (Belclare $\times$ Scottish Blackface or crossbreds involving only lowland breeds such as Suffolk, Galway and Belclare) or purebred Finnish Landrace. The results (in Expt 1, Table 3) show that the Finnish Landrace and Belclare $\times$ Scottish Blackface give significantly better pregnancy rates than the lowland-type crossbreds, most of which were Suffolk crosses. A subsequent study (Expt 2 in Table 3) was designed to compare a wider range of breeds including purebred Suffolk, Texel, Belclare and Finnish Landrace ewes. The time of insemination relative to removal of progestogen pessaries was the same $(+57 \mathrm{~h})$ for all breeds. The results confirmed that there are large differences due to ewe breed. 
Table 4. Effect of ewe breed ( $n=40 / \mathrm{breed}$ ) on the interval ( \pm SE) from progestogen withdrawal to preovulatory $\mathrm{LH}$ surge and to onset of ovulation

\begin{tabular}{lcr}
\hline & \multicolumn{2}{c}{ Interval (h) to } \\
\cline { 2 - 3 } Breed & LH surge & Ovulation \\
\hline Finnish Landrace & $34.0 \pm 0.98$ & $56.1 \pm 0.86$ \\
Suffolk & $35.5 \pm 1.07$ & $57.5 \pm 0.90$ \\
Texel & $36.7 \pm 1.00$ & $58.3 \pm 0.87$ \\
Scottish Blackface & $36.4 \pm 0.98$ & $60.7 \pm 0.86$ \\
\hline
\end{tabular}

Data from Donovan et als (2000).

Breed effects on the timing of ovulation, and hence inappropriate timing of $\mathrm{Al}$, were considered as a possible explanation for the major breed differences revealed in these studies. However, follow-up studies involving Finnish Landrace, Suffolk, Texel and Scottish Blackface purebred ewes did not support this hypothesis (Table 4) as there were no significant differences among breeds for the intervals from progestogen withdrawal to either the preovulatory surge or to ovulation (Donovan et al., 2000).

It is clear from this series of experiments that there are major differences due to the breed of ewe in the success of cervical Al using frozen-thawed semen. The elucidation of the reasons for these differences should provide valuable insights on how cervical Al with frozen-thawed semen can be made sufficiently successful to be used in practical breeding programmes.

\section{Variation in semen among males}

All of the Al experiments that we have conducted involved semen frozen from individual rams. A consistent feature of the results is significant variation among rams with respect to the pregnancy rate achieved. This was true for both Norwegian and Irish semen. Similar findings have been reported for laparoscopic insemination of frozen-thawed ram semen (Eppleston and Maxwell, 1995) and for semen from bucks (Corteel et al., 1987). Analysis of our results yields an estimate of 14 percentage points for the standard deviation of the true ram effects on pregnancy rate. With such variation among individual rams in the success rate of cervical Al with frozen-thawed semen, considerable gains in pregnancy rate can be achieved by preselection of rams. Thus, if the best $20 \%$ of rams could be identified this would increase the pregnancy rate by $15-20$ percentage points.

This finding raises the question of how to establish the fertilizing ability of frozen-thawed semen. Does this require an actual field trial? The reliability of a field trial with 40 ewes inseminated per male is about 0.8 given the results indicated above. Although such an approach would not be impracticable, it would obviously be desirable to identify effective quality assessment systems that can provide sufficiently accurate in vitro evidence for selection of rams. In this context, it is worth bearing in mind that such procedures would allow the testing of a much greater number of rams and, consequently, have the opportunity for more intense selection of a panel for use in an Al programme. Such procedures would also enable effective quality control across collections from the same ram (Windsor, 1997).

Opportunities exist for significant advances in the understanding of the factors that determine the success of cervical Al with frozen-thawed semen given the variations outlined above. The large differences among ewe breeds provides a lever for evaluating the importance of variation in transport through the cervical barrier, survival in the uterus and physiological mechanisms governing the milieu at the site of fertilization. The relatively 
large variation among individual rams in the fertilizing ability of semen has implications for research on protocols for cryopreservation, in vitro evaluation of semen after thawing and the possibilities for developing effective screening methods for selecting rams for use in Al. The application of molecular techniques to the study of this variation should have the potential to yield significant advances in the pregnancy rate resulting from cervical Al of frozen-thawed semen (Holt, 2000). One potentially fruitful approach would be the identification of rams the semen of which yields either good or poor pregnancy rate and the establishment of a bank of semen from such individuals as an experimental resource.

\section{Conclusions}

The fact that neither the Booroola nor Inverdale mutations are responsible for the major gene effects that have been demonstrated in at least six sheep populations with major genes for ovulation rate implies that further insights on the control of ovarian function are likely in the near future. The large response to selection on ovulation rate in Finn sheep without any evidence for the involvement of a major gene indicates quite a different pathway from that involved in the Booroola and Inverdale cases. The evidence for genetic variation in the distribution of ovulation rate indicates that this could be exploited to minimize the incidence of triplet and higher order births in prolific strains. This may be a more productive approach to reducing the perinatal mortality penalty incurred by triplet and higher order births than direct selection on offspring survival.

Major challenges and opportunities are indicated from recent studies of sheep Al using frozen-thawed semen. It is concluded that pregnancy rates in the region of $60 \%$ would be attainable in many breeds if differences among males in the 'quality' of their 'frozen-thawed' semen could be effectively exploited. It seems reasonable to conclude that the application of the techniques of molecular biology to the elucidation of these differences should provide significant advances in the exploitation of artificial insemination in genetic improvement programmes in small ruminants.

\section{References}

Amer PR, McEwan JC, Dodds KG and Davis GH (1999) Economic values for ewe prolificacy and lamb survival in New Zealand sheep Livestock Production Science 5875 -90

Andersen Berg K and Aamdal J (1991) Artificial insemination with frozen semen in ewes at different times of the breeding season Reproduction in Domestic Animals 26 27-30

Bodin L, Reinaud P, Layones D, Poivey JP and Charpigny G (1994) Relationship between embryonic interferon (OTP) and embryo survival in sheep Proceedings of the 5th World Congress on Genetics Applied to Livestock Production 19 245-248

Bodin L, Elsen JM, Poivey JP, SanCristobal-Gaudy M, Belloc JP and Eychenne F (1998) Hyper-prolificacy in the French Lacaune sheep breed: a possible major gene Proceedings of the 6th World Congress on Genetics Applied to Livestock Production 27 11-14

Bodin L, SanCristobal M, Lecerf F, Mulsant P, Bibe B, Lajous D, Belloc JP, Eychenne F, Amigues $Y$ and Elsen JM (2002) Segregation of a major gene influencing ovulation in progeny of Lacaune meat sheep Genetics Selection Evölution 34 447-464

Bradford GE (1985) Selection for litter size. In Genetics of Reproduction in Sheep pp 3-18. Eds RB Land and DW Robinson. Butterworths, London

Bradford GE, Quirke JF, Sitorius P, Inounu I, Tiesnamurti B, Bell FL, Fletcher IC and Torell DT (1986) Reproduction in Javanese sheep: evidence for a gene with large effect on ovulation rate and litter size Journal of Animal Science 63 418-431

Braw-Tal R, McNatty KP, Smith P, Heath DA, Hudson NL, Phillips DJ, McLeod BJ and Davis GH (1993) Ovaries of ewes homozygous for the X-linked Inverdale gene (FecX') are devoid of secondary and tertiary follicles but contain many abnormal structures Biology of Reproduction 49 895-907

Cloete SWP and Scholtz AJ (1998) Lamb survival in relation to lambing and neonatal behaviour in medium wool Merino lines divergently selected for multiple rearing ability Australian fournal of Experimentaf Agriculture $38801-811$ 
Corteel JM, Baril G and Leboeuf B (1987) Development of artificial insemination with deep-frozen semen and out-of-season breeding of goats in France Proceedings of 4 th International Goat Conference Brasilia $1523-547$

Davis GH, Montgomery GW, Allison AJ, Kelly RW and Bray AR (1982) Segregation of a major gene influencing fecundity in progeny of Booroola sheep New Zealand Journal of Agricultural Research 25 $525-529$

Davis GH, Shackell GH and Kyle SE (1991a) A putative major gene for prolificacy in Romney sheep. In Major Genes for Reproduction in Sheep, 2 nd International Workshop, Les Colloques, No. 57 pp 61-65 Eds JM Elsen, L Bodin and I Thimonier. INRA, Paris

Davis GH, McEwan JC, Fennessy PF, Dodds KG and Farquhar PA (1991b) Evidence for the presence of a major gene influencing ovulation rate on the $X$ chromosome of sheep Biology of Reproduction 44 620-624

Davis GH, McEwan IC, Fennessy PF, Dodds KG, McNatty KP and Wai-Sum O (1992) Infertility due to bilateral ovarian hypoplasia in sheep homozygous (FecX' FecX') for the Inverdale prolificacy gene located on the $X$ chromosome Biology of Reproduction 46 636-640

Davis GH, Dodds KG, Wheeler R and Jay NP (2001) Evidence that an imprinted gene on the $X$ chromosome increases ovulation rate in sheep Biology of Reproduction $64216-221$

Davis GH, Galloway SM, Ross IK et al. (2002) DNA tests in prolific sheep from eight countries provide new evidence on origin of the Booroola (FecB) mutation Biology of Reproduction $\mathbf{6 6} 1869$ 1874

Demiroren E, Shresta INB and Boylan WJ (1995) Breed and environmental effects on components of ewe productivity in terms of multiple births, artificial rearing and 8-month breeding cycles Small Ruminant Research 16 239-249

Dickerson G (1970) Efficiency of animal production moulding the biological components Journal of Animal Science 30 849-859

Dong J, Albertini DF, Mishimori K, Kumar TR, Lu N and Matzui MM (1996) Growth differentiation factor-9 is required during early ovarian folliculogenesis Nature $383531-535$

Donovan A, Hanrahan JP, Kummen E, Duffy P and Boland MP (1998) Ewe fertility following cervical Al of fresh or frozen-thawed semen at a natural or synchronised oestrus Irish Journal of Agricultural and Food Research 37 108-109

Donovan A, Hanrahan JP, Duffy P, Byrne GP and Boland MP (1999) Cervical AI with fresh or frozen-thawed semen: effect of ewe breed Irish Journal of Agricultural and Food Research 38267 (Abstract)

Donovan A, Hanrahan JP, Duffy P and Boland MP (2000) $\mathrm{Al}$ in sheep: breed differences in timing of ovulation Irish Journal of Agriculural and Food Research $39464-465$

Donovan A, Hanrahan IP, Lally T, Boland MP, Byrne GP, Duffy P, Lonergan P and $\mathbf{O}^{\prime}$ Neill DJ (2001) Al for Sheep Using Frozen-thawed Semen 36 pages Teagasc, Ireland

Elsen IM, Bodin L, Francois D, Poivy IP and Teyssier J (1994) Genetic improvement of litter size in sheep Proceedings of the 5th World Congress on Genetics Applied to Livestock Production 19 237-243

Eppleston J and Maxwell WMC (1995) Sources of variation in the reproductive performance of ewes inseminated with frozen-thawed ram semen by laparoscopy Theriogenology $43777-788$

Evans G and Maxwell WMC (1987) Salamon's Artificial Insemination of Sheep and Goats 194 pages Butterworth, Sydney, NSW

Fahmy MH (1996) Prolific Sheep CAB International, Oxon, UK

Fogarty NM (1995) Genetic parameters for liveweight, fat and muscle measurements, wool production and reproduction in sheep: a review Animal Breeding Abstracts 63 101-143

Galloway SM, McNatty KP, Cambridge LM et al. (2000) Mutations in an oocyte-derived growth factor gene (BMP15) cause increased ovulation rate and infertility in a dosage-sensitive manner Nature Genetics $25279-283$

Gordon 1 (1997) Controlled Reproduction in Sheep and Goats CAB International, Oxon, UK

Hanrahan IP (1980) Ovulation rate as the selection criterion for litter size in sheep Proceedings of the Australian Society of Animal Production 13 405-408

Hanrahan JP (1982) Selection for increased ovulation rate, litter size and embryo survival Proceedings of the 2nd World Congress on Genetics Applied to Livestock Production 5 294-309

Hanrahan JP (1986) Reproductive efficiency in sheep. In Exploiting New Technologies in Animal Breeding pp 59-70 Eds C Smith, JWB King and JC McKay. Oxford University Press, Oxford

Hanrahan JP (1991) Evidence for single gene effects on ovulation rate in the Cambridge and Belclare breeds. In Major Genes for Reproduction in Sheep, 2nd International Workshop, Les Colloques, No. 57 pp 93102 Eds JM Elsen, L Bodin and J Thimonier. INRA, Paris

Hanrahan JP (1997) Ovarian hypoplasia in Cambridge and Belclare ewes. In Belclare Research Centre Research Report p 24. Teagasc, Dublin

Hanrahan JP (2001) Autosomal gene affecting the structure and function of the sheep ovary Proceedings of Agricultural Research Forum p 50. Irish Grassland and Animal Production Association

Hanrahan JP (2002) Response to divergent selection for ovulation rate in Finn sheep. In Proceedings of the 7th World Congress on Genetics Applied to Livestock Production 30 673-676 
Hanrahan JP and Owen JB (1985) Variation and repeatability of ovulation rate in Cambridge ewes Animal Production 40529 (Abstract)

Hanrahan JP, Adalsteinson S, Thorgeirsson S, Thorsteinsson SS and Eythorsdottir E (1989) Ovulation rate and embryo survival in Icelandic ewes Animal Production 48 619-620

Holt WV (2000) Basic aspects of frozen storage of semen Animal Reproduction Science 62 3-22

Jonmundsson JV and Adalsteinsson S (1985) Single genes for fecundity in Icelandic sheep, In Genetics of Reproduction in Sheep pp 159-168 Eds RB Land and DW Robinson. Butterworths, London

Large RV (1970) The biological efficiency of meat production in sheep Animal Production 12 393-401

Leboeuf B, Restall B and Salamon S (2000) Production and storage of goat semen for artificial insemination Animal Reproduction Science 62 113-141

Mahieu M, Jego Y, Driancourt MA and Chemineau P (1989) Reproductive performance of Creole and Blackbelly ewes in the West Indies. A new major gene controlling ovulation rate Animal Reproduction Science 19 235-243

Matos CAP, Thomas DC, Youd LD and Gianola D (2000) Genetic analyses of lamb survival in Rambouillet and Finn sheep ilocks by linear and threshold models Journal of Animal Science 71 227-234

Montgomery GW, Galloway SM, Davis GH and McNatty KP (2001) Genes controlling ovulation rate in sheep Reproduction 121 843-852

Mulsant P, Lecerf F, Fabre S et al. (2001) Mutation in bone morphogenetic protein receptor-1 $\beta$ is associated with increased ovulation rate in Booroola Merino ewes Proceedings National Academy of Science USA $985104-5109$

O'Callaghan D and Boland MP (1999) Nutritional effects on ovulation, embryo development and the establishment of pregnancy in ruminants Anima/ Science 68 299-314

Olesen I (1993) Effects of cervical insemination with frozen semen on fertility and litter size of Norwegian sheep Livestock Production Science 37 169-184

Owen JB (1971) Increasing reproductive efficiency of sheep. 10th World Congress of Animal Production, Versailles, Theme II p 4

Piper LR and Bindon BM (1982) Genetic segregation for fecundity in Booroola Merino sheep. In Proceedings of World Congress on Sheep and Beef Cattle Breeding 1 395-400 Eds RA Barton and WC Smith. The Dunmore Press Ltd. Palmerston North, New Zealand

Radomska MJ, Martyniuk E, Klewiec J and Knothe A (1988) Inheritance of high prolificacy of the Olkuska sheep (preliminary results) Journal of Agricultural Science Finland $\mathbf{6 0} 597-598$

Reeve ECR and Robertson FW (1953) Factors affecting multiple births in sheep Animal Breeding Abstracts 21 211-224

Ricordeau G, Razungles J and Lajous D (1982) Heritability of ovulation rate and level of embryonic losses in the Romanov breed Proceedings of the 2nd World Congress on Genetics Applied to Livestock Production $7591-595$

Robinson JI, Sinclair KD and McEvoy TG (1999) Nutritional effecis on foetal growih Animal Science 68 315-331

Salamon S and Maxwell WMC (2000) Storage of ram semen Animal Reproduction Science 62 77-111

Timon VM, More $\mathrm{O}^{\prime}$ Farrell GJ, Flanagan J and Vial VE (1963) The genetic improvement of hill and lowland ewes 3. High Fertility ewes. In Animal Production Division Research Report p 78. An Foras Taluntais, Dublin

Turner HN (1982) Origins of the CSIRO Booroola. In The Booroola Merino pp 1-7 Eds LR Piper, BM Bindon and RD Nethery. CSIRO, Melbourne

Turner HN, Hayman LK, Triffit LK and Prunster RW (1962) Response to selection for multiple births in the Australian Merino: a progress report Animal Production 4 165-176

Wallace LR (1958) Breeding Romneys for better lambing percentages New Zealand Journal of Agriculture 97 $545-550$

Wilson T, Wu Xi-Yang, Juengel IL ef al. (2001) Highly prolific Booroola sheep have a mutation in the intracellular kinase domain of bone morphogenetic protein IB receptor (ALK-6) that is expressed in both oocytes and granulosa cells Biology of Reproduction $641225-1235$

Windsor DP (1997) Variation between ejaculates in the fertility of frozen ram semen used for cervical insemination of Merino ewes Animal Reproduction Science $4721-39$ 